\title{
Reading as a Basis of Vocabulary Growth: Application to an EFL Setting
}

\author{
Tran B. Vo, MA TESOL student \\ T.Vo11@westcliff.edu
}

\begin{abstract}
This paper will explore the critical roles of vocabulary development and teaching reading as a basis of vocabulary growth in an advanced English as a Foreign Language (EFL) classroom. An application is promoted from the discussion, which identifies the interrelation between reading and vocabulary growth (Krashen, 1989; Horst, Cobb, Cobb, \& Meara, 1998; Waring \&Nation, 2004; Hunt \& Beglar; 2005). The quality of a reading text and the learners' interests are considerations that must be taken into account for improved vocabulary instruction.
\end{abstract}




\section{INTRODUCTION}

The recent growing demand of learning English as a foreign language in Vietnam has been reflected through the accelerating rates of overseas study opportunities and the emergence of accreditation programs. In 2017, about 130,000 Vietnamese students attended academic programs outside of Vietnam, in roughly 50 countries, thus doubling the figure from 2009 (Viet, 2017). According to the Vietnamese Ministry of Education and Training (MoET), during the first quarters in 2017, 84 universities and colleges all over the country were offering accreditation programs in 273 programs in numerous fields, the most popular of which were Business Administration and Finance (MoET, 2017). There were eight programs related to the English language (MoET, 2017). Students who attended these programs needed to prove competency in lexis and reading skills. August, Carlo, Dressler and Snow (2005), in highlighting the role of vocabulary development, stated that students' limited lexicons might increase the risk of students' developing a learning disability. Exposure to reading materials in English throughout these specified programs has enhanced the participating students' vocabulary development. Being alert to this understanding, the Premier Language School in Ho Chi Minh City has been incorporating reading and vocabulary instruction into their curriculum through a course entitled, Vocabulary Building and Reading Comprehension (VR). This course is dedicated to advanced learners who need to improve their vocabulary repertories and reading skills either for academic or professional purposes. These conditions initiated the premise of this research in identifying the contribution of teaching reading to students' vocabulary development, especially in enriching lexicons.

\section{ReAding AS Fundamental to VocabulaRY GROWTH}

Krashen (1989) asserts that spelling and vocabulary competence are both subconsciously acquired through comprehensible written input. This process is referred to as incidental learning. Waring and Nation (2004) perpetuate this assertion by exploring the relationship between reading in a foreign language and lexical acquisition. It was found that reading helped to improve the vocabulary learning process (Waring \& Nation, 2004). Most research suggests learners be introduced to 3-6 new words for every hour of reading (Waring \& Nation, 2004). Regardless of the relatively low average rate of vocabulary gained $(13.8 \%)$, the benefits are increased through repeated encounters (Waring \& Nation, 2004). Horst, Cobb, Cobb, and Meara (1998) agreed that extensive reading helped learners to enrich their personal database of words, improve lexical access speed, and build network linkages among words.

\section{Pedagogical Application}

The contributions of reading to vocabulary growth are monumental. Thus, it is essential for the pedagogical implications to be explored. Below is an acquisitive analysis of the requirements for selecting a reading text. Following the analysis is a specific reading text, which serves as a sample that is applicable for students when focusing on vocabulary development. 


\section{REQUIREMENTS OF READING TEXTS}

An effective reading text should meet the following criteria. First, implicit instruction should occur through meaningfocused reading, thus, increasing vocabulary size through extensive reading and fluency development (Hunt \& Beglar, 2005). Second, extensive reading should ensure a word-rich environment that can invigorate vocabulary size. Students should be able to select materials that suit their interests (Hunt \& Beglar, 2005). Third, a core topic with integrated tasks such as discussions or watching videos and narrow reading can enhance levels of lexical access and reading fluency (Hunt \& Beglar, 2005). Next, reading texts should be easy to read and be appropriate for the given level. The coverage rate, the amount of vocabulary the readers know, should be at least 98\% (Waring \& Nation, 2004). In addition, reading texts must foster word consciousness (Schmitt, 2000).

\section{AN INCIDENTAL READING TEXT}

A reading text (see Appendix) was selected with intensive consideration based on the criteria discussed above. The $98.25 \%$ coverage rate of the words the students were familiar with throughout text guarantees a sustainable number of new words, i.e. 10 new words over 572 words, for students of the advanced level. The core topic of this text is the Son Doong Cave, the world's largest and most unique cave in Vietnam. This cave has attracted both domestic and international concerns as there is a current fight to save it. Thus, this topic has the potential to engage students in reading the text. The informative and thoughtful message of the text is suitable for advanced learners. If possible, pictures of the cave should be presented to raise excitement levels and interest in the content previous to reading the text. This story is an example of the incorporation of authentic material as it was found in the Huffington Post. Articles in the Huffington Post are of high lexical quality and are able to create a word-rich environment for vocabulary learning. The paragraphs were numbered to make the text easier to read. Finally, identifying the new word's word functions (see Appendix) rejuvenates students' word consciousness.

\section{CONCLUSION AND IMPLICATIONS}

Extensive reading is truly beneficial for vocabulary development, an essential element in foreign language acquisition. In material design, teachers should take into account the following: meaning-focused reading, fluency development, vocabulary size enhancement, a core topic, a word-rich environment, word consciousness, and reader-friendliness. The reading text suggested above can be incorporated into either an in-class reading comprehension practice or a summative assessment like homework. Another implication idea is for students to practice guessing the meaning of new words by using context clues. 


\section{APPENDIX}

\section{Reading Text}

Before you read: There are 10 new words in this article. As you read it, identify these words' functions. Do not look at the glossary until you finish reading the article.

\section{In Vietnam, A Rush to Save the World's Largest Cave from the Masses}

By Nick Visser - Huffington Post

"Caves are fragile environments. They don't regenerate very quickly, and once they're broken, they're broken.”

1.The world's largest cave, the mammoth Hang Son Doong in Vietnam, is a relative babe-in-arms when it comes to natural history: The cavern was first discovered in 1991, then lost, then found again before it was first explored in 2009. But less than a decade later, environmentalists are scrambling to save the site from thousands of tourists and a development company set on thrusting a cable car into its depths.

2.Located in Phong Nha-Ke Bang national park, a UNESCO World Heritage Site, Son Doong stretches more than 5.5 miles underground, reaches heights of 650 feet and is home to its own jungle, ecosystem and river. Just one tour company has a concession to venture into the cave, and only a few hundred people are allowed inside the fragile environment every year. But that could soon change.

3.HuffPost RYOT spoke with local activists, cavers and the spelunkers who first explored Son Doong about the local government's secretive plans that may allow developers to build a massive cable car project that' $\mathrm{d}$ bring more than 1,000 people to the cave each day.

Such threats are not new.

4.In 2014, a group of local activists helped stave off a proposal to build a $\$ 212$ million, 6.5-mile-long cable car throughout Phong Nha-Ke Bang park that would traverse parts of Son Doong. The announcement drew widespread condemnation despite assurances from the cable car company, Sun Group, that it would be an environmentally friendly way to view the park that'd bring "thousands of jobs for the poor local people."

5.Any plans at Son Doong would likely echo another project, completed by another company last year, at the country's Mount Fansipan, one of the tallest peaks in the region. The site is now home to a cable car that cut a journey that used to take three days on foot down to 20 minutes. The system can now bring 2,000 people to the summit every hour, and, like the country's iconic Ha Long Bay, has become a hive of tourist activity.

6.Environmentalists fear that if the Son Doong project were to go forward, it would bring hordes of tourists to a pristine ecosystem protected by its relative unreachability.

7.A Facebook group operating under the name Save Son Doong has called on the Vietnamese government to again reject the proposal, saying the "project must be stopped before it has a huge and damaging impact on the Son Doong cave and the ecosystem of the entire Phong Nha-Ke Bang national park," a Change.org petition organized by the group says.

8.Those concerns were echoed by the British Cave Research Association, the group that declared Son Doong the largest of its kind and, alongside the explorer Howard Limbert, led the first expedition to the site. 
9.“Caves are fragile environments. They don't regenerate very quickly, and once they're broken, they're broken," Deb Limbert, a team leader for the group, told HuffPost RYOT.Government officials in the province of Quang Binh, where Son Doong is located, have told local media there are no plans to support a new cable car project.In March, HuffPost RYOT filmed a representative of the cable car company traveling to the cave with Phong Nha-Ke Bang park employees.

Visser, N. (2017, March 21). In Vietnam, a rush to save the world's largest cave from the masses. Retrieved from https:/www.huffingtonpost.com/entry/son-doong-cave-vietnam-cable-carplan_us_58c67dc2e4b054a0ea6ba11f

Glossary (from Merriam-Webster Dictionary)

a mammoth(n) - something immense (supremely good) of its kind

a cavern (n) - a cave; especially : one of large or indefinite extent

scrambling(adj.) from to scramble (v) - to struggle eagerly or unceremoniously for possession of something

to thrust st.(v) - to push or drive with force

to venture $(\mathrm{v})$ - to proceed especially in the face of danger

a spelunker (n) - one who makes a hobby of exploring and studying caves

stave off(v) - to fend off

to traversest. $(\mathrm{v})$ - to move or pass along or through

hordes(n) - a large unorganized group of individuals

pristine(adj.) - not spoiled, corrupted, or polluted (as by civilization) 


\section{REFERENCES}

August, D., Carlo, M., Dressler, C., \& Snow, C. (2005). The critical role of vocabulary development for English language learners. Learning Disabilities Research \& Practice, 20(1), 50-57. Retrieved from https://macmillanmh.com/LAUSD_econsultant/rla/assets/papers/vocabdev_ell.pdf

Horst, M., Cobb, T., Cobb, T., \& Meara, P. (1998). Beyond a clockwork orange: Acquiring second language vocabulary through reading. Reading in a Foreign Language, 11(2), 207-223. Retrieved from https://www.lextutor.ca/cv/beyond_a_clockwork_orange.html

Hunt, A., \& Beglar, D. (2005). A framework for developing EFL reading vocabulary. Reading in a Foreign Language, 17(1), 23. Retrieved from https://files.eric.ed.gov/fulltext/EJ689121.pdf

Krashen, S. (1989). We acquire vocabulary and spelling by reading: Additional evidence for the input hypothesis. The Modern Language Journal, 73(4), 440-464. Retrieved from https://s3.amazonaws.com/academia.edu.documents/33988299/krashen1989.pdf?AWSAccessKeyld=AKI AIWOWYYGZ2Y53UL3A\&Expires=1521299166\&Signature=VGzIA\%2BEg6TZ4\%2Ffm\%2BS5t6LtoCrnw\%3D\& response-content-disposition=inline\%3B\%20filename\%3DKrashen1989.pdf

Schmitt, N. (2000). Vocabulary in language teaching. Cambridge University Press.

Thornbury, S. (2002). How to teach vocabulary. Harlow, Essex: Pearson Education Limited.

Waring, R., \& Nation, I. S. P. (2004). Second language reading and incidental vocabulary learning. Angles on the English-Speaking World, 4, 97-110. Retrieved from http://geolangs.org/archives/sla/waring120304.pdf

List of accreditation programs approved by MoET. (2017). In VIED. Retrieved from http://vied.vn/imgs/2017/03/LKDT_21.3.2017.pdf

Viet, N. (2017, March 7). Du họcsinhViệt Nam ở nướcngoàităngmạnh (The acceleration of the number of Vietnamese overseas students). Retrieved from http://baoquangnam.vn/the-gioi/201703/du-hoc-sinhviet-nam-o-nuoc-ngoai-tang-manh-726389/

Visser, N. (2017, March 21). In Vietnam, a rush to save the world's largest cave from the masses. Retrieved from https://www.huffingtonpost.com/entry/son-doong-cave-vietnam-cable-carplan_us_58c67dc2e4b054a0ea6ba11f 